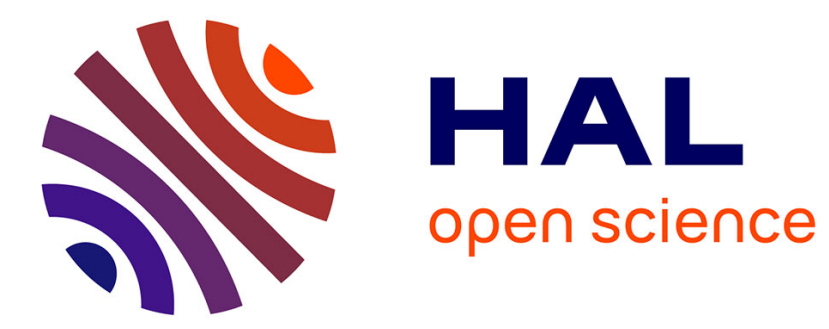

\title{
Modern PET imaging for paragangliomas: Relation to genetic mutations
}

D. Taïeb, D. Rubello, A. Al-Nahhas, M. Calzada, M.C. Marzola, E. Hindié

\section{To cite this version:}

D. Taïeb, D. Rubello, A. Al-Nahhas, M. Calzada, M.C. Marzola, et al.. Modern PET imaging for paragangliomas: Relation to genetic mutations. EJSO - European Journal of Surgical Oncology, 2011, 37 (8), pp.662. 10.1016/j.ejso.2011.05.004 . hal-00715503

\section{HAL Id: hal-00715503 \\ https://hal.science/hal-00715503}

Submitted on 8 Jul 2012

HAL is a multi-disciplinary open access archive for the deposit and dissemination of scientific research documents, whether they are published or not. The documents may come from teaching and research institutions in France or abroad, or from public or private research centers.
L'archive ouverte pluridisciplinaire HAL, est destinée au dépôt et à la diffusion de documents scientifiques de niveau recherche, publiés ou non, émanant des établissements d'enseignement et de recherche français ou étrangers, des laboratoires publics ou privés. 


\section{Accepted Manuscript}

Title: Modern PET imaging for paragangliomas: Relation to genetic mutations

Authors: D. Taïeb, D. Rubello, A. Al-Nahhas, M. Calzada, M.C. Marzola, E. Hindié

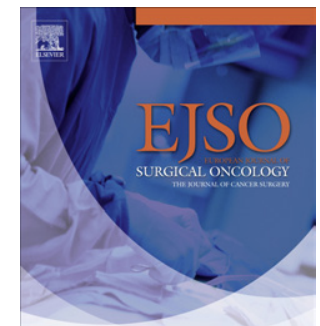

PII: S0748-7983(11)00288-5

DOI: $\quad$ 10.1016/j.ejso.2011.05.004

Reference: $\quad$ YEJSO 3163

To appear in: European Journal of Surgical Oncology

Accepted Date: 9 May 2011

Please cite this article as: Taïeb D, Rubello D, Al-Nahhas A, Calzada M, Marzola MC, Hindié E. Modern PET imaging for paragangliomas: Relation to genetic mutations, European Journal of Surgical Oncology (2011), doi: 10.1016/j.ejso.2011.05.004

This is a PDF file of an unedited manuscript that has been accepted for publication. As a service to our customers we are providing this early version of the manuscript. The manuscript will undergo copyediting, typesetting, and review of the resulting proof before it is published in its final form. Please note that during the production process errors may be discovered which could affect the content, and all legal disclaimers that apply to the journal pertain. 
Re-revised version - May 2, 2011

\title{
Modern PET imaging for paragangliomas: relation to genetic mutations
}

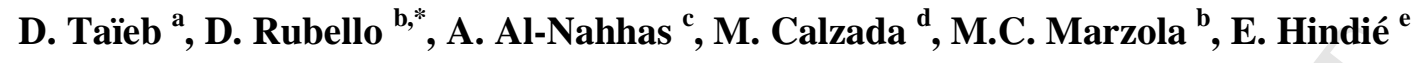 \\ ${ }^{a}$ Department of Nuclear Medicine, Centre hospitalo-universitaire Timone, Marseille, France \\ ${ }^{b}$ Department of Nuclear Medicine, PET/CT Centre, Radiology, Medical Physics, 'Santa \\ Maria della Misericordia' Hospital, Rovigo, Italy \\ ${ }^{c}$ Department of Nuclear Medicine, Hammersmith Hospital, London, UK \\ ${ }^{d}$ Department of Nuclear Medicine, Hôpital Saint-Antoine, Paris, France \\ ${ }^{e}$ Department of Nuclear Medicine, Hôpital Saint-Louis, Université Paris7, Paris, France
}

Running head: New tracers for paragangliomas

\section{*Corresponding author:}

Domenico Rubello, Director Department of Nuclear Medicine, PET/CT, Radiology, Medical Physics, 'Santa Maria della Misericordia' Hospital, Via Tre Martiri 150, 45100 Rovigo, Italy: Tel.: +39 425 4428; Fax: +3942539 4434;

E-mail address: domenico.rubello@1ibero.it

Conflict of interest statement: the authors declare no conflict of interest. 


\begin{abstract}
Aim and Methods: Paragangliomas (PGL) are neural crest-derived tumours that are found along the autonomic neural network throughout the body and can be multiple and/or metastatic. Nuclear medicine imaging in combination with conventional imaging is required to fully delineate the extent of the disease. The performance of molecular imaging modalities is widely dependent on tumour biology.

Results: In the present paper we discuss the recent publications focused on the role of positron emission tomography (PET) imaging and the relationship between tracer uptake patterns and genetic mutations associated with the disease.

Conclusion: Recent advances in genetic and molecular pathogenesis of PGL have allowed for the identification of new molecular diagnostic and therapeutic radiopharmaceuticals tailored to genetic abnormalities. However, the optimal diagnostic imaging algorithm remains to be determined.
\end{abstract}

Keywords: Paraganglioma; Genetic mutations; Positron-emission tomography; radiopharmaceuticals 


\section{Introduction}

Paragangliomas (PGL) are part of a family of highly vascularized neural crest-derived neoplasms originating in the adrenal medulla, chemoreceptors or autonomic ganglia. PGL are found throughout the body in association with either the sympathetic or parasympathetic systems. PGL involving the adrenal glands are called phaeochromocytomas. Extra-adrenal PGL can be associated with the parasympathetic system and found in the head, neck and mediastinum. Those associated with the sympathetic system predominate in the retroperitoneum along the thoracolumbar para-aortic region. In contrast to other endocrine tumours, a high proportion $(>20 \%)$ of patients carry germline mutations that predispose to multifocality.

Six major genes (SDHB, SDHC, SDHD, VHL, RET, NF1) are involved in tumorigenesis. SDHx and VHL gene mutations predispose to adrenal and extra-adrenal PGL whereas RET and NF1 mutations are associated with adrenal PGL (often bilateral). Head and neck (H\&N) PGL and tendency for multifocal involvement are more frequently associated with SDHD compared to SDHB; whereas malignancy is strongly associated with SDHB mutations (37.5\% vs. $3.1 \%$ for SDHD). ${ }^{1,2}$ Current knowledge of the disorders associated with SDHC mutations is still limited but typically PGL originate from the parasympathetic ganglia.

\section{Challenges of modern imaging}

It is expected that the early detection of PGL may minimize complications related to mass effect and hormonal excess, facilitate curative treatment and potentially reduce the metastatic spread. One important but unresolved question is whether early detection of very small and biochemically silent PGL in family members would improve the prognosis of patients.

\section{Functional imaging}


Functional imaging is probably not necessary for most adrenal PGL (sporadic, $<5 \mathrm{~cm}$ ). ${ }^{3} \mathrm{By}$ contrast, in malignant and multifocal forms (often inherited), the role of pre therapy imaging is crucial for providing accurate staging of the disease. In this respect, nuclear imaging in combination with conventional imaging may be required to fully delineate the extent of the disease. Radiolabelled metaiodobenzylguanidine (MIBG) and somatostatin analogues are the traditional imaging procedures. $\left[{ }^{131} \mathrm{I} /{ }^{123} \mathrm{I}\right] \mathrm{MIBG}$ scintigraphy is the most widely used tracer for detecting abdominal PGL, while $\left[{ }^{111} \mathrm{In}\right]$ pentetreotide-SPECT can be more sensitive in $\mathrm{H} \& \mathrm{~N}$ PGL. ${ }^{4}$ They represent the gold standard functional imaging modalities for sporadic PGL. However, $\left[{ }^{131} \mathrm{I} /{ }^{123} \mathrm{I}\right] \mathrm{MIBG}$ and $\left[{ }^{111} \mathrm{In}\right]$ pentetreotide scintigraphy demonstrate a suboptimal sensitivity due to the detection limits of conventional gamma camera imaging, although the contribution of SPECT/CT has led to significant improvement in the diagnostic confidence in image interpretation. Therefore, significant underestimation of the disease may occur in patients at risk of multifocality and/or malignancy. More recently, the use of positron emission tomography (PET) imaging in this group of tumours is growing rapidly, paralleled by great efforts towards the development of new tracers.

\section{PET tracers}

PGL are characterized by their high density of peptide receptors, their ability to take up amino acids and decarboxylate them into biogenic amines and their high glucose uptake. These features are used for nuclear imaging targeting by using specific and non-specific PET tracers.

Figure 1 shows the mechanism of uptake into PGL cells for four different PET tracers.

\section{[18F]Fluorodeoxyglucose}

$[18 \mathrm{~F}]$ Fluorodeoxyglucose $\left(\left[{ }^{18} \mathrm{~F}\right] \mathrm{FDG}\right)$ is taken up via glucose transporters and phosphorylated by hexokinase into $\left[{ }^{18} \mathrm{~F}\right] \mathrm{FDG}-6 \mathrm{P}$. However, increased $\left[{ }^{18} \mathrm{~F}\right] \mathrm{FDG}$ uptake is not 
limited to malignancy and many oncogenetic signals are also present in some benign PGL that may result in increased glucose uptake (i.e., mutations in VHL and SDHx genes). ${ }^{5}$

\section{$\left.{ }^{18} \mathrm{~F}\right]$-dihydroxyphenylalanine}

Dihydroxyphenylalanine (DOPA) is a precursor to Dopamine and, $\left[{ }^{18} \mathrm{~F}\right]-$ dihydroxyphenylalanine $\left(\left[{ }^{18} \mathrm{~F}\right] \mathrm{FDOPA}\right)$ shows characteristically high uptake in PGL cells, which are offspring from the amine precursor uptake and decarboxylation (APUD) stem cells. $\left[{ }^{18} \mathrm{~F}\right]$ FDOPA is transported into cells via sodium-independent large neutral amino acids transporter type 1 (LAT1), and decarboxylated into Fluorodopamine by the enzyme aromatic L-amino acid decarboxylase (AADC) and stored in cytoplasmic neurosecretory granules via vesicular monoamine transporters (VMAT1/2).

\section{${ }^{18}$ FJFluorodopamine}

By contrast, another tracer, $\left[{ }^{18} \mathrm{~F}\right]$ Fluorodopamine $\left(\left[{ }^{18} \mathrm{~F}\right] \mathrm{FDA}\right.$ is taken up by to the cytosol via the same cell membrane transporters that take up MIBG (norepinephrine transporter, NET) and stored into vesicles. Dopamine type 2 receptor (D2DR) is also expressed in PGL and may influence the patterns of $\left[{ }^{18} \mathrm{~F}\right] \mathrm{FDA}$ uptake. ${ }^{6,7,8}$

\section{${ }^{8} \mathrm{Ga}$-labelled somatostatin analogue peptides}

$\left[{ }^{68} \mathrm{Ga}\right]$-PET has emerged as an alternative to cyclotron-based PET radiopharmaceuticals. $\left[{ }^{68} \mathrm{Ga}\right]$-labelled somatostatin analogue peptides $\left(\left[{ }^{68} \mathrm{Ga}\right] \mathrm{SSTa}\right)$ directly bind to somatostatin receptors (SSTR) on the tumour cells surface and are internalized within the receptors. PGL are characterized by their high density in SSTRs, especially the subtype 2 (SSTR2). ${ }^{9}$ The mechanisms of uptake and retention of several tracers in tumour cells are depicted in Figure 1 and Table 1. 


\section{Preliminary data from PET tracers}

Different PET tracers have thus been evaluated in clinical studies: $\left[{ }^{11} \mathrm{C}\right]$ hydroxyephedrine (not discussed), $\left[{ }^{18} \mathrm{~F}\right] \mathrm{FDG},\left[{ }^{18} \mathrm{~F}\right] \mathrm{FDOPA},\left[{ }^{18} \mathrm{~F}\right] \mathrm{FDA}$ and $\left[{ }^{68} \mathrm{Ga}\right]-$ labelled somatostatin analogs $\left(\left[{ }^{68} \mathrm{Ga}\right] \mathrm{SSTa}\right)$. Analysis of the relevant literature is hampered by the frequent mixing of both sympathetic and parasympathetic PGL.

\section{$I^{18} F J F D G-P E T$}

The performance of $\left[{ }^{18}\right.$ F]FDG-PET has been extensively evaluated only recently in PGL because of its lack of specificity and the initial disappointing results. ${ }^{10}$ Several studies have found that $\left[{ }^{18}\right.$ F]FDG-PET was sensitive in the evaluation of PGL. ${ }^{11,12,13,14,15}$ It should be noted that the vast majority of patients had abdominal and or malignant forms, making it impossible to fully extrapolate the results for head and neck $(\mathrm{H} \& \mathrm{~N})$ lesions. By contrast to medullary thyroid carcinomas and digestive endocrine tumours which tend to increase their glucose avidity in the later stages of the disease, $\left[{ }^{18} \mathrm{~F}\right] \mathrm{FDG}-\mathrm{PET}$ should be considered as a new molecular signature of PGL that could occur in the benign form of the disease. ${ }^{12}$ Patients with catecholamine-secreting PGL may also have brown adipose tissue activation and uptake of $\left[{ }^{18}\right.$ F]FDG. ${ }^{16}$ It is now established that tumours that carry SDHB mutations have higher glucose uptake values $^{12,14,15}$ (an example is shown in Figure 2). It is probable that these mutations could participate in metabolic reprogramming in tumour cells. Since SDH are mitochondrial proteins of the tricarboxylic acid cycle and the respiratory chain, mutations could impair energy production and in turn induce upregulation of genes involved in angiogenesis, glucose uptake and consumption by the tumour. Transcriptional profiling studies reveal pseudohypoxic signatures in SDHx/VHL tumours that differentiate them from RET/NF1 cases. ${ }^{17,18}$ Glucose transporters (GLUT) may play an important role in mediating tumour glucose uptake [17]. However, overexpression of hypoxic-inducible factor (HIF)-1 $\alpha$ 
target genes is mainly found in VHL tumours due to the decrease in VHL-mediated degradation of HIF-1 $\alpha .{ }^{17}$ Further studies are thus required to understand the molecular basis of glucose avidity of SDHx tumours.

$I^{18} F J F D A$

$\left[{ }^{18} \mathrm{~F}\right] \mathrm{FDA}$ is an experimental radiotracer that has been developed and evaluated at the National Institutes of Health in Bethesda. ${ }^{15,19,20,21,22}\left[{ }^{18}\right.$ F]FDA-PET was found to be more sensitive $(76 \%)$ than $\left[{ }^{18} \mathrm{~F}\right] \mathrm{FDOPA}-\mathrm{PET}(45 \%)$ and $\left[{ }^{123} \mathrm{I}\right]-\mathrm{MIBG}(57 \%)$ in the detection of metastatic deposits. In non-metastatic PGL, differences between imaging modalities did not achieve statistical significance. In their prospective study, Timmers et al recommend $\left[{ }^{18} \mathrm{~F}\right]$ FDOPA-PET in patients with an unknown genotype, $\left[{ }^{18} \mathrm{~F}\right] \mathrm{FDG}$ and PET in SDHB mutation carriers, and $\left[{ }^{18} \mathrm{~F}\right] \mathrm{FDOPA}$ or $\left[{ }^{18} \mathrm{~F}\right] \mathrm{FDA}$ PET in non-SDHB patients. ${ }^{20}$

\section{$I^{18}$ F Fluoride}

Since bone metastases frequently occur in metastatic PGL, $\left[{ }^{18}\right.$ F $]$ Fluoride-PET might emerge as a sensitive diagnostic tool and replace bone scintigraphy in these patients. ${ }^{15,23}$

\section{$I^{18} F J F D O P A$}

Several studies have addressed the issues of $\left[{ }^{18} \mathrm{~F}\right]$ FDOPA-PET in non-metastatic and metastatic PGL. ${ }^{13,20,24,25,26,27,28,29,30,31,32,33,34}$ To date, $\left[{ }^{18}\right.$ F]FDOPA-PET could be the most sensitive tracer for detecting H\&N PGL $25,27,30,31,35$ (Figure 3). High tumour avidity and favorable signal to noise ratio in the head and neck allows the detection of very small PGL by $\left[{ }^{18}\right.$ F $]$ FDOPA-PET. However, $\left[{ }^{18}\right.$ F]FDOPA-PET should not be considered simply as an MIBG scan with higher sensitivity but rather a new specific radiotracer with its own advantages and limitations. $\left[{ }^{18} \mathrm{~F}\right] \mathrm{FDOPA}-\mathrm{PET} / \mathrm{CT}$ is a promising tool for detecting adrenal PGL with sensitivity ranging from 85 to $100 \% .{ }^{29,32}$ The main advantage of the technique over $\left[{ }^{123} \mathrm{I}\right]-$ 
MIBG and $\left[{ }^{18} \mathrm{~F}\right] \mathrm{FDA}$ is that there is low physiological $\left[{ }^{18} \mathrm{~F}\right] \mathrm{FDOPA}$ uptake in healthy adrenal tissue that facilitates the diagnosis of adrenal PGL in patients at risk of bilateral lesions (i.e., MEN2, NF1). ${ }^{28,32}$ Two studies have demonstrated that $\left[{ }^{18}\right.$ F $]$ FDOPA could miss abdominal PGL otherwise detected by MIBG scan and/or $\left[{ }^{18}\right.$ F $]$ FDG-PET ${ }^{25,26}$ Fottner et al demonstrated that tumour expression of vesicular monoamine transporter type 1 (VMAT-1) is critical for detection by MIBG-scintigraphy. ${ }^{20}$ This is particularly important in the management of SDHD patients who are susceptible to develop both parasympathetic and sympathetic PGL. Charrier et al recently found that $\left[{ }^{18} \mathrm{~F}\right] \mathrm{FDOPA}-\mathrm{PET}$ was more sensitive than $\left[{ }^{111} \mathrm{In}\right]$ pentetreotide-SPECT in the diagnosis of H\&N PGL (96.7\% versus $66.7 \%$, respectively). ${ }^{25}$ Only one carotid body PGL was missed by $\left[{ }^{18}\right.$ F]FDOPA-PET but pathological analysis showed this to be an atypical PGL that was fibrosed. In a recent series of nine patients with H\&N PGL (total of 18 lesions), $\left[{ }^{18}\right.$ F]FDOPA-PET detected all lesions (18/18) compared to $\left[{ }^{18}\right.$ F]FDG $(16 / 18),\left[{ }^{111}\right.$ In]-pentetreotide scintigraphy $(11 / 17),\left[{ }^{18} \mathrm{~F}\right] \mathrm{FDA}(8 / 18)$ and $\left[{ }^{123} \mathrm{~F}\right] \mathrm{MIBG}(5 / 18) .{ }^{30}$ Carbidopa, which decreases the decarboxylation and subsequent renal clearance of DOPA may be used to increase the tumour-to-background ratio of tracer uptake but had a low influence on the number of lesions depicted with $\left[{ }^{18}\right.$ F]FDOPA-PET since the vast majority of tumours had high uptake values. ${ }^{33}$

\section{${ }^{68} \mathrm{GaJSSTa}$}

In recent years, $\left[{ }^{68} \mathrm{Ga}\right]$-DOTA-somatostatin analogue peptides that directly bind to somatostatin receptors on the tumour cells surface have been employed for the evaluation of neuroendocrine tumours with excellent results. Among the different peptides, $\left[{ }^{68} \mathrm{Ga}\right]$-DOTANOC may offer the advantage over others (TOC, TATE) to target a broader range of somatostatin receptors with high affinity for SSTR $2 .^{36}$ 
Studies have shown the superiority of PET over $\left[{ }^{111}\right.$ In]pentetreotide-SPECT in the detection of metastases and unknown primary neuroendocrine tumours. PET imaging using $\left[{ }^{68} \mathrm{Ga}\right] \mathrm{SSTa}$ was also more accurate than $\left[{ }^{18} \mathrm{~F}\right] \mathrm{FDOPA}-\mathrm{PET}$ in non carcinoid tumours. To date, the role of these emerging tracers in PGL is limited to case series. ${ }^{37,38,39,40,41,42}$

Recently, Naji et al found that $\left[{ }^{68} \mathrm{Ga}\right]-D O T A-T A T E$ detected more tumour sites than $\left[{ }^{123} \mathrm{I}\right]-$ MIBG in patients with neural crest tumours (including 11 PGL). Only one bone lesion in one patient with adrenal PGL was detected on $\left[{ }^{123} \mathrm{I}\right]-\mathrm{MIBG}$ scan but not in $\left[{ }^{68} \mathrm{Ga}\right]-\mathrm{DOTA}-\mathrm{TATE}$. One additional lesion in a SDHB patient was missed by both modalities but detected with $\left[{ }^{18} \mathrm{~F}\right]$ FDG-PET ${ }^{38}$

\section{Conclusion and perspectives}

The performance of molecular imaging modalities is widely dependent on tumour biology. Recent advances in genetic and molecular pathogenesis of PGL have allowed for the identification of new molecular diagnostic and therapeutic radiopharmaceuticals tailored to genetic abnormalities. However, the optimal diagnostic imaging algorithm remains to be determined..$^{35,43}$

\section{Proposed diagnostic algorithm}

According to the literature, $\left[{ }^{18} \mathrm{~F}\right]$ FDOPA-PET should replace $\left[{ }^{111} \mathrm{In}\right]$ pentetreotide-SPECT as the first-line imaging in $\mathrm{H} \& \mathrm{~N}$ PGL, but MIBG scan may be still required in combination with $\left[{ }^{18}\right.$ F]FDOPA-PET in cases of abdominal and malignant forms. $\left[{ }^{18}\right.$ F]FDG may add further information in SDHB mutation carriers, especially those with multifocal and/or metastatic disease. If available, $\left[{ }^{18} \mathrm{~F}\right] \mathrm{FDA}$ seems to be a highly sensitive tracer in metastatic adrenal PGL and should be the first-line imaging method in non-SDHB inherited patients.

\section{Perspectives}


The above described tailored algorithm may of course further evolve if a future head to head comparison of $\left[{ }^{18} \mathrm{~F}\right]$ FDOPA-PET and $\left[{ }^{68} \mathrm{Ga}\right] \mathrm{SST}$-PET in patients with parasympathetic PGL offers a new insight. PET imaging should also be considered for delineation of radiotherapy target volumes in H\&N PGL, especially after debulking surgery. A summary of clinical indications of selected tracers are listed in Table 2.

The MIBG analogues $\left[{ }^{124} \mathrm{I}\right]-\mathrm{MIBG}$, meta- $\left[{ }^{76} \mathrm{Br}\right]$ bromobenzylguanidine $\left(\left[{ }^{76} \mathrm{Br}\right]-\mathrm{MBBG}\right)$, and $4-\left[{ }^{18} \mathrm{~F}\right]$-fluoro-3-IBG have been suggested and used in few studies but to our knowledge, no clinical studies have yet been reported. ${ }^{44,45}$ Many other peptide receptors are overexpressed in endocrine tumours and thus could represent new emerging targets for diagnosis and therapy. The influence of some new drugs on tracer uptake is also subjet to investigations. ${ }^{46}$

One point is clear, the way to image PGL is changing and nuclear medicine has a leading role to play. 


\section{Legend to Figures and Tables}

Figure 1. Schematic display of mechanisms of uptake and retention of several PET tracers in tumour cells of neural crest origin

$\left[{ }^{18} \mathrm{~F}\right]: \quad$ Fluorine-18; $\quad\left[{ }^{18} \mathrm{~F}\right] \mathrm{FDG}: \quad[18 \mathrm{~F}]$ Fluorodeoxyglucose; $\quad\left[{ }^{18} \mathrm{~F}\right] \mathrm{FDOPA}: \quad\left[{ }^{18} \mathrm{~F}\right]-$ dihydroxyphenylalanine; $\quad\left[{ }^{18} \mathrm{~F}\right] \mathrm{FDA}: \quad\left[{ }^{18} \mathrm{~F}\right]$ Fluorodopamine; $\quad\left[{ }^{68} \mathrm{Ga}\right] \mathrm{SSTa}: \quad\left[{ }^{68} \mathrm{Ga}\right]$-labelled somatostatin analogues; HK: Hexokinase, AADC: Aromatic L-amino decarboxylase, SSTR2 : Somatostatin receptor type 2; SSTa : Somatostatin analogues; ${ }^{68} \mathrm{Ga}:$ Gallium-68; GLUT : Glucose transporters; NET : Norepinephrine transporter; LAT1: sodium-independent large neutral amino acids transporter type 1, requires dimerization with CD98 for its targeting to the plasma membrane; VMAT : vesicular monoamine transporter 1 and 2.

\section{Figure 2. $\left[{ }^{18}\right.$ F]FDG PET in a non metastatic SDHB-related left adrenal paraganglioma.} Marked FDG tumour avidity (SUVmax 50) without any extra-adrenal foci. Axial CT view (A), axial attenuation-corrected $\left[{ }^{18}\right.$ F]FDG-PET image (B), axial PET/CT fusion image (C), Maximum-Intensity-Projection (MIP) image (D). Pathological examination (E) revealed a 33 $\mathrm{mm}$ tumour without any unfavorable histological features (PASS score 0 , Ki-67<1\%, no mitosis).

Figure 3. $\left[{ }^{18}\right.$ F]FDOPA PET in a SDHD-patient with multiple paragangliomas in the neck and the abdomen.

Coronal whole-body images showing bilateral neck and abdominal extra-adrenal paragangliomas (A), Maximum-Intensity-Projection (MIP) image (B), Axial (C), coronal (D) and sagittal (E) PET/CT views centered over the para-aortic abdominal parasympathetic paragangliomas. 
Table 1. Summary of approved and experimental tracers.

Table 2. Summary of selected tracers used as first and second-line imaging modalities. 
Table 1

\begin{tabular}{|c|c|c|c|c|c|}
\hline & Current status & Specificity & $\begin{array}{l}\text { Targeting } \\
\text { pathway }\end{array}$ & $\begin{array}{c}\text { Mechanism of } \\
\text { Uptake }\end{array}$ & $\begin{array}{l}\text { Mechanism of } \\
\text { retention }\end{array}$ \\
\hline$[18 \mathrm{~F}]-\mathrm{FDG}$ & Approved & Tumour cells & $\begin{array}{c}\text { Glucose uptake, } \\
\text { Energy } \\
\text { metabolism, } \\
\text { Vessels density, } \\
\text { Angiogenesis } \\
\text { (VEGF-A), } \\
\text { Hypoxia }\end{array}$ & $\begin{array}{c}\text { Glucose } \\
\text { transporters }\end{array}$ & $\begin{array}{c}\text { Phosphorylation } \\
\text { (Hexokinase) }\end{array}$ \\
\hline $\begin{array}{c}{[123 \mathrm{I}]-\mathrm{MIBG}} \\
{[18 \mathrm{~F}]-\mathrm{FDA}} \\
(*)\end{array}$ & $\begin{array}{c}\text { Approved } \\
\text { Experimental }\end{array}$ & Chromaffin cells & $\begin{array}{l}\text { Catecholamine } \\
\text { biosynthesis }\end{array}$ & NET & $\begin{array}{c}\text { Storage in } \\
\text { vesicles } \\
\text { (VMATs) }\end{array}$ \\
\hline $\begin{array}{l}\text { [18F]- } \\
\text { FDOPA }\end{array}$ & Approved & APUD cells & $\begin{array}{c}\text { Aminoacid } \\
\text { uptake and } \\
\text { decarboxylation }\end{array}$ & LAT1 & $\begin{array}{c}\text { Decarboxylation } \\
\text { (AADC) }\end{array}$ \\
\hline $\begin{array}{c}\text { [68Ga]- } \\
\text { SSTa }\end{array}$ & Experimental & Endocrine cells & $\begin{array}{l}\text { Somatostatin } \\
\text { uptake and } \\
\text { internalization }\end{array}$ & $\begin{array}{c}\text { SSTRx } \\
\text { (especially type } \\
2) \\
\text { Internalization } \\
(* *)\end{array}$ & Internalization \\
\hline
\end{tabular}

${ }^{*}[11 \mathrm{C}]$-Hydroxyephedrine belongs to this category.

${ }^{*}$ Trapping is also dependent on the internalization of the tracer

$\left[{ }^{18} \mathrm{~F}\right] \mathrm{FDG}:[18 \mathrm{~F}]$ Fluorodeoxyglucose; [123I]metaiodobenzylguanidine; [18F]Fluorodeoxyglucose; $\left[{ }^{18} \mathrm{~F}\right] \mathrm{FDOPA}:\left[{ }^{18} \mathrm{~F}\right]-$ dihydroxyphenylalanine; $\left[{ }^{18} \mathrm{~F}\right] \mathrm{FDA}$ :

$\left[{ }^{18} \mathrm{~F}\right]$ Fluorodopamine; $\left[{ }^{68} \mathrm{Ga}\right] \mathrm{SST}$ : $\left.:{ }^{68} \mathrm{Ga}\right]$-labelled somatostatin analogues; APUD: amine precursor uptake and decarboxylation; VEGF-A: Vascular endothelial growth factor A; NET: Norepinephrine transporter; LAT1: sodium-independent large neutral amino acids transporter type 1; SSTRx:

Somatostatin receptors; VMATs: vesicular monoamine transporter 1 and 2; AADC: aromatic L-amino acid decarboxylase 
Table 2

\begin{tabular}{cccc}
\hline & $\begin{array}{c}\text { Non metastatic } \\
\text { abdominal PGL }\end{array}$ & $\begin{array}{c}\text { Non metastatic } \\
\text { H\&N PGL }\end{array}$ & Metastatic PGL \\
\hline $\mathbf{1}^{\text {st }}$ Line & {$[123 \mathrm{I}]-\mathrm{MIBG}$} & {$[18 \mathrm{~F}]-\mathrm{FDOPA}$} & {$[123 \mathrm{I}]-\mathrm{MIBG}$} \\
\hline $\mathbf{2}^{\text {nd }}$ Line & {$[18 \mathrm{~F}]-\mathrm{FDOPA}$} & $\begin{array}{c}{[111 \mathrm{In}]-} \\
\text { Pententreotide }\end{array}$ & {$[18 \mathrm{~F}]-\mathrm{FDG}$} \\
& {$[123 \mathrm{I}]-\mathrm{MIBG}^{2}$} & {$[18 \mathrm{~F}]-\mathrm{FDOPA}{ }^{3}$} \\
& & & \\
\hline $\begin{array}{c}\text { Experimental } \\
\text { tracers }\end{array}$ & {$[18 \mathrm{~F}]-\mathrm{FDA}$} & {$[68 \mathrm{Ga}]-S S T a$} & {$[18 \mathrm{~F}]-\mathrm{FDA}$} \\
\hline
\end{tabular}

${ }^{1}[111 \mathrm{In}]-$ Pententreotide is performed when diagnosis of H\&N PGL remains uncertain on [18F]-FDOPA.

${ }^{2}$ [123I]-MIBG is performed when abdominal tumour sites are suspected on $\mathrm{Cl}$, [18F]-FDOPA or in cases of previous history of abdominal surgery for PGL and/or presence of SDHD mutation.

${ }^{3}[18 F]-F D O P A$ is more sensitive in non-SDHB than in SDHB-related metastatic PGL. 


\section{References}

1. Burnichon N, Rohmer V, Amar L, et al. The succinate dehydrogenase genetic testing in a large prospective series of patients with paragangliomas. J Clin Endocrinol Metab 2009;94:2817-27.

2. Ricketts CJ, Forman JR, Rattenberry E, et al. Tumor risks and genotype-phenotypeproteotype analysis in 358 patients with germline mutations in SDHB and SDHD. Hum Mutat 2010;31:41-51.

3. Taieb D, Sebag F, Hubbard JG, Mundler O, Henry JF, Conte-Devolx B. Does iodine131 meta-iodobenzylguanidine (MIBG) scintigraphy have an impact on the management of sporadic and familial phaeochromocytoma? Clin Endocrinol (Oxf) 2004;61:102-8.

4. Koopmans KP, Jager PL, Kema IP, Kerstens MN, Albers F, Dullaart RP. 111Inoctreotide is superior to 123I-metaiodobenzylguanidine for scintigraphic detection of head and neck paragangliomas. $J$ Nucl Med 2008;49:1232-7.

5. Kroemer G, Pouyssegur J. Tumor cell metabolism: cancer's Achilles' heel. Cancer Cell 2008;13:472-82.

6. Pivonello R, Ferone D, de Herder WW, et al. Dopamine receptor expression and function in human normal adrenal gland and adrenal tumors. $J$ Clin Endocrinol Metab 2004;89:4493-502.

7. Pupilli C, Lanzillotti R, Fiorelli G, et al. Dopamine D2 receptor gene expression and binding sites in adrenal medulla and pheochromocytoma. J Clin Endocrinol Metab 1994;79:56-61.

8. Saveanu A, Muresan M, De Micco C, et al. Expression of somatostatin receptors, dopamine D2 receptors, noradrenaline transporters and vesicular monoamine transporters in 52 pheochromocytomas and paragangliomas. Endocr Relat Cancer 2011; In press.

9. Reubi JC, Waser B, Khosla S, et al. In vitro and in vivo detection of somatostatin receptors in pheochromocytomas and paragangliomas. $J$ Clin Endocrinol Metab 1992;74:1082-9.

10. Shulkin BL, Thompson NW, Shapiro B, Francis IR, Sisson JC. Pheochromocytomas: imaging with 2-[fluorine-18]fluoro-2-deoxy-D-glucose PET. Radiology 1999;212:35-41.

11. Shulkin BL, Koeppe RA, Francis IR, Deeb GM, Lloyd RV, Thompson NW. Pheochromocytomas that do not accumulate metaiodobenzylguanidine: localization with PET and administration of FDG. Radiology 1993;186:711-5.

12. Taieb D, Sebag F, Barlier A, et al. 18F-FDG avidity of pheochromocytomas and paragangliomas: a new molecular imaging signature? J Nucl Med 2009;50:711-7.

13. Taieb D, Tessonnier L, Sebag F, et al. The role of 18F-FDOPA and 18F-FDG-PET in the management of malignant and multifocal phaeochromocytomas. Clin Endocrinol 2008;69:580-6.

14. Timmers HJ, Kozupa A, Chen CC, et al. Superiority of fluorodeoxyglucose positron emission tomography to other functional imaging techniques in the evaluation of metastatic SDHB-associated pheochromocytoma and paraganglioma. J Clin Oncol 2007;25:2262-9.

15. Zelinka T, Timmers HJ, Kozupa A, et al. Role of positron emission tomography and bone scintigraphy in the evaluation of bone involvement in metastatic pheochromocytoma and paraganglioma: specific implications for succinate dehydrogenase enzyme subunit B gene mutations. Endocr Relat Cancer 2008;15:311-23.

16. Hadi M, Chen CC, Whatley M, Pacak K, Carrasquillo JA. Brown fat imaging with (18)F-6-fluorodopamine PET/CT, (18)F-FDG PET/CT, and (123)I-MIBG SPECT: a study of patients being evaluated for pheochromocytoma. J Nucl Med 2007;48:1077-83.

17. Favier J, Briere JJ, Burnichon N, et al. The Warburg effect is genetically determined in inherited pheochromocytomas. PLoS One 2009;4:e7094. 
18. Lopez-Jimenez E, Gomez-Lopez G, Leandro-Garcia LJ, et al. Research Resource: Transcriptional Profiling Reveals Different Pseudohypoxic Signatures in SDHB and VHLRelated Pheochromocytomas. Mol Endocrinol 2010;24:2382-91.

19. Ilias I, Chen CC, Carrasquillo JA, et al. Comparison of 6-18F-fluorodopamine PET with 123I-metaiodobenzylguanidine and 111in-pentetreotide scintigraphy in localization of nonmetastatic and metastatic pheochromocytoma. J Nucl Med 2008;49:1613-9.

20. Timmers HJ, Chen CC, Carrasquillo JA, et al. Comparison of 18F-Fluoro-L-DOPA, 18F-Fluoro-Deoxyglucose, and 18F-Fluorodopamine PET and 123I-MIBG Scintigraphy in the localization of pheochromocytoma and paraganglioma. J Clin Endocrinol Metab 2009;94:4757-67.

21. Timmers HJ, Eisenhofer G, Carrasquillo JA, et al. Use of 6-[18F]-fluorodopamine positron emission tomography (PET) as first-line investigation for the diagnosis and localization of non-metastatic and metastatic phaeochromocytoma (PHEO). Clin Endocrinol 2009;71:11-7.

22. Mamede M, Carrasquillo JA, Chen CC, et al. Discordant localization of 2-[18F]fluoro-2-deoxy-D-glucose in 6-[18F]-fluorodopamine- and [(123)I]metaiodobenzylguanidine-negative metastatic pheochromocytoma sites. Nucl Med Commun 2006;27:31-6.

23. Iagaru A, Mittra E, Yaghoubi SS, et al. Novel strategy for a cocktail 18F-fluoride and 18F-FDG PET/CT scan for evaluation of malignancy: results of the pilot-phase study. $J$ Nucl Med 2009;50:501-5.

24. Brink I, Schaefer O, Walz M, Neumann HP. Fluorine-18 DOPA PET imaging of paraganglioma syndrome. Clin Nucl Med 2006;31:39-41.

25. Charrier N, Deveze A, Fakhry N, et al. Comparison of [111In]pentetreotide-SPECT and $[18 \mathrm{~F}]$ FDOPA-PET in the localization of extra-adrenal paragangliomas: The case for a patient-tailored use of nuclear imaging modalities. Clin Endocrinol (Oxf) 2010; In press.

26. Fottner C, Helisch A, Anlauf M, et al. 6-18F-fluoro-L-dihydroxyphenylalanine positron emission tomography is superior to 123I-metaiodobenzyl-guanidine scintigraphy in the detection of extraadrenal and hereditary pheochromocytomas and paragangliomas: correlation with vesicular monoamine transporter expression. J Clin Endocrinol Metab 2010;95:2800-10.

27. Hoegerle S, Ghanem N, Altehoefer C, et al. 18F-DOPA positron emission tomography for the detection of glomus tumours. Eur J Nucl Med Mol Imaging 2003;30:689-94.

28. Hoegerle S, Nitzsche E, Altehoefer C, et al. Pheochromocytomas: detection with $18 \mathrm{~F}$ DOPA whole body PET--initial results. Radiology 2002;222:507-12.

29. Imani F, Agopian VG, Auerbach MS, et al. 18F-FDOPA PET and PET/CT accurately localize pheochromocytomas. J Nucl Med 2009;50:513-9.

30. King KS, Alexopoulos DK, Whatley MA, et al. Functional imaging of head and neck paragangliomas: comparison of 18F-Fluorodihydroxyphenylalanine (18F-FDOPA) positron emission tomography (PET), 18F-Fluorodopamine (18F-FDA) PET/computed tomography (CT), 18F-fluoro-2-deoxy-d glucose (18F-FDG) PET/CT, 123I-Metaiodobenzylguanidine (123I-MIBG) scintigraphy, and 111In-Pentetreotide scintigraphy. Endocr Rev 2010;31:S841.

31. King KS, Whatley MA, Alexopoulos DK, et al. The use of functional imaging in a patient with head and neck paragangliomas. J Clin Endocrinol Metab 2010;95:481-2.

32. Luster $\mathrm{M}$, Karges $\mathrm{W}$, Zeich $\mathrm{K}$, et al. Clinical value of 18Ffluorodihydroxyphenylalanine positron emission tomography/computed tomography (18FDOPA PET/CT) for detecting pheochromocytoma. Eur J Nucl Med Mol Imaging 2010;37:484-93. 
33. Timmers HJ, Hadi M, Carrasquillo JA, et al. The effects of carbidopa on uptake of 618F-Fluoro-L-DOPA in PET of pheochromocytoma and extraadrenal abdominal paraganglioma. J Nucl Med 2007;48:1599-606.

34. Fiebrich HB, Brouwers AH, Kerstens MN, et al. 6-[F-18]Fluoro-Ldihydroxyphenylalanine positron emission tomography is superior to conventional imaging with (123)I-metaiodobenzylguanidine scintigraphy, computer tomography, and magnetic resonance imaging in localizing tumors causing catecholamine excess. J Clin Endocrinol Metab 2009;94:3922-30.

35. Rubello D, Grasseto G. Integrated diagnostic imaging in pheochromocytoma and paraganglioma. L'Endocrinologo 2010;11:54-64.

36. Wild D, Macke HR, Waser B, et al. 68Ga-DOTANOC: a first compound for PET imaging with high affinity for somatostatin receptor subtypes 2 and 5. Eur J Nucl Med Mol Imaging 2005;32:724.

37. Ambrosini V, Tomassetti P, Castellucci P, et al. Comparison between 68Ga-DOTANOC and 18F-DOPA PET for the detection of gastro-entero-pancreatic and lung neuroendocrine tumours. Eur J Nucl Med Mol Imaging 2008;35:1431-8.

38. Naji M, Zhao C, Welsh SJ, et al. (68)Ga-DOTA-TATE PET vs. (123)I-MIBG in identifying malignant neural crest tumours. Mol Imaging Biol 2010; (in press).

39. Win Z, Al-Nahhas A, Towey D, et al. 68Ga-DOTATATE PET in neuroectodermal tumours: first experience. Nucl Med Commun 2007;28:359-63.

40. Ambrosini V, Campana D, Bodei L, et al. 68Ga-DOTANOC PET/CT clinical impact in patients with neuroendocrine tumors. $J$ Nucl Med 2010;51:669-73.

41. Fanti S, Ambrosini V, Tomassetti P, et al. Evaluation of unusual neuroendocrine tumours by means of 68Ga-DOTA-NOC PET. Biomed Pharmacother 2008;62:667-71.

42. Win Z, Rahman L, Murrell J, Todd J, Al-Nahhas A. The possible role of 68GaDOTATATE PET in malignant abdominal paraganglioma. Eur J Nucl Med Mol Imaging 2006;33:506.

43. Havekes B, King K, Lai EW, Romijn JA, Corssmit EP, Pacak K. New imaging approaches to phaeochromocytomas and paragangliomas. Clin Endocrinol 2010;72:137-45.

44. Loc'h C, Mardon K, Valette H, et al. Preparation and pharmacological characterization of [76Br]-meta-bromobenzylguanidine ([76Br]MBBG). Nucl Med Biol 1994;21:49-55.

45. Vaidyanathan G, Affleck DJ, Zalutsky MR. Validation of 4-[fluorine-18]fluoro-3iodobenzylguanidine as a positron-emitting analog of MIBG. J Nucl Med 1995;36:644-50.

46. Martiniova L, Perera SM, Brouwers FM, et al. Increased uptake of [123I]metaiodobenzylguanidine, $[18 \mathrm{~F}]$ fluorodopamine and $[3 \mathrm{H}]$ norepinephrine in mouse pheochromocytoma cells and tumors after treatment with the histone deacetylase inhibitors. Endocr Relat Cancer 2010; In press. 


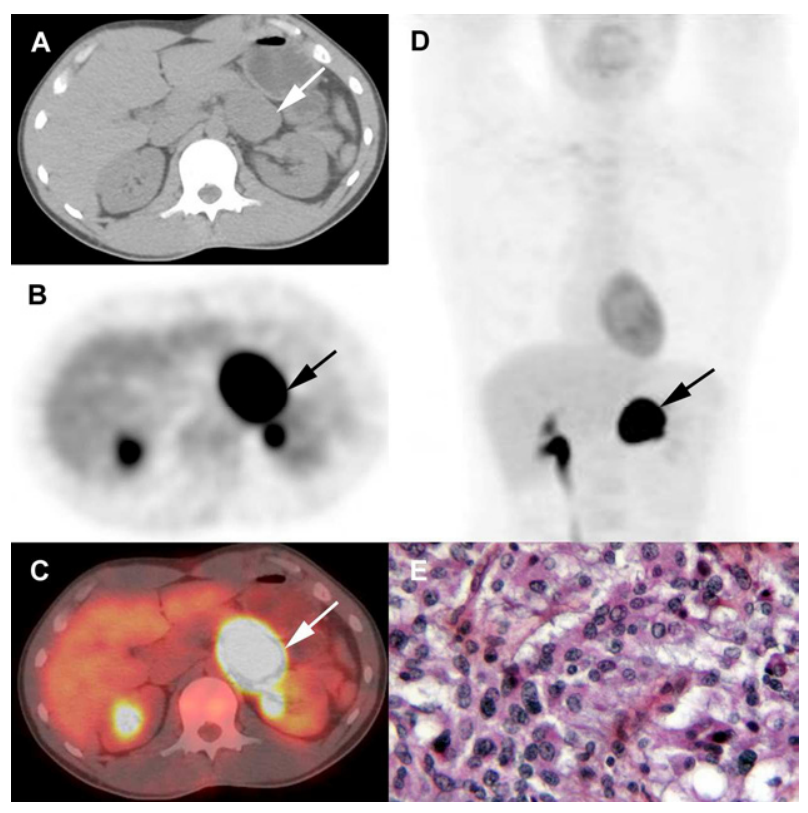




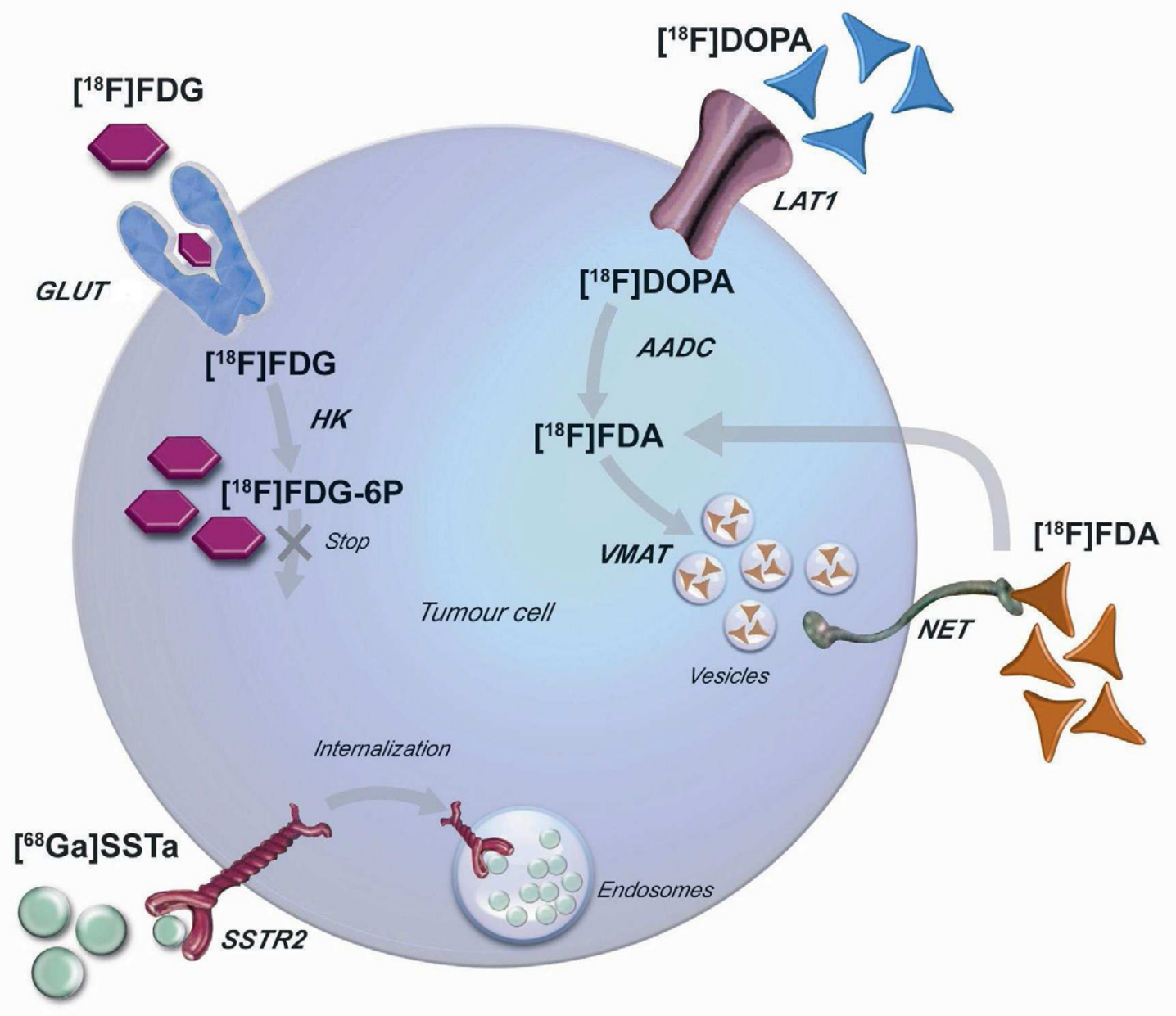




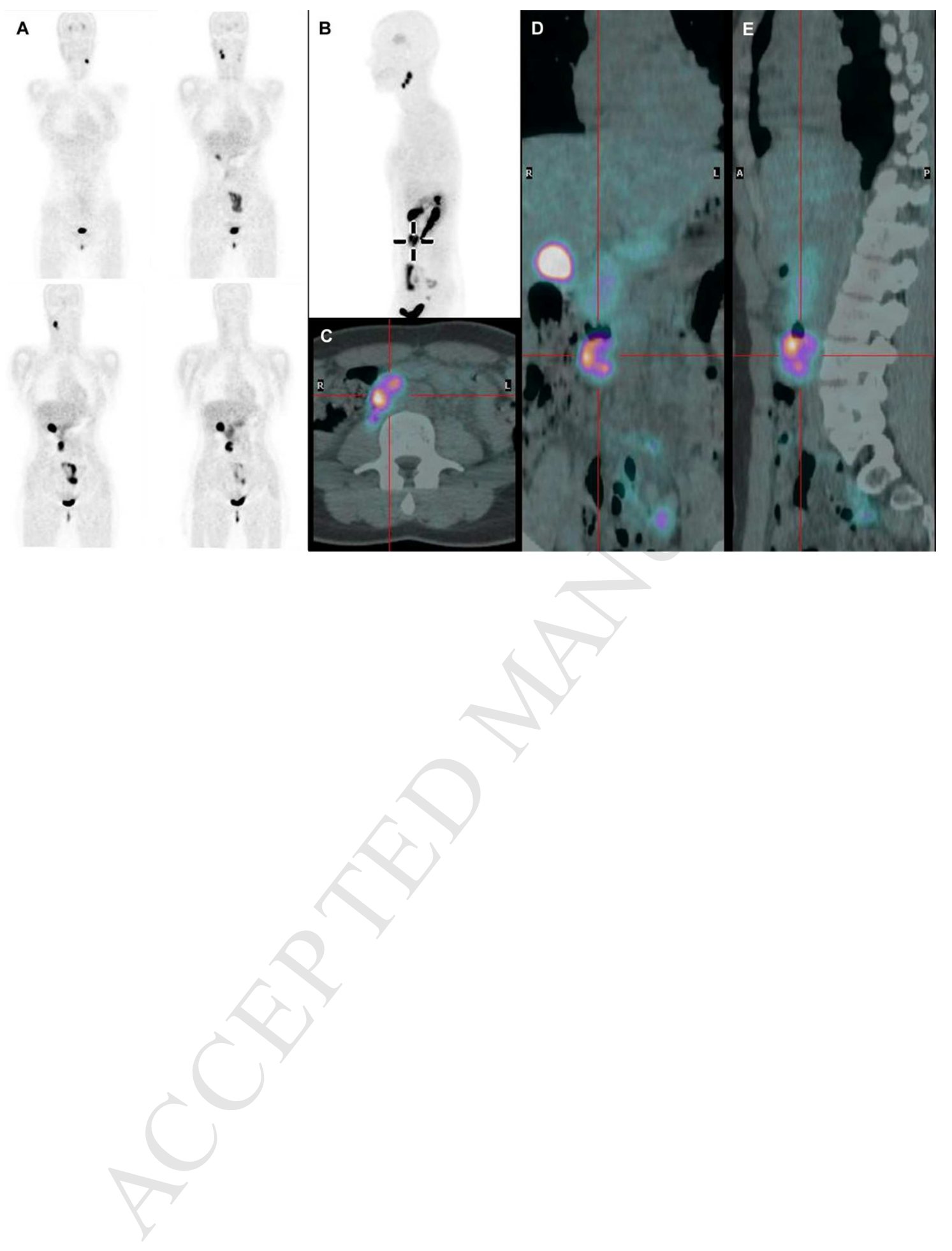

